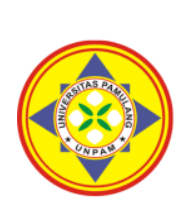

\title{
PENGARUH CAPITAL ADEQUACY RATIO (CAR) DAN BIAYA \\ OPERASIONAL PENDAPATAN OPERASIONAL (BOPO) TERHADAP RETURN ON ASSET (ROA) PADA PT. BANK SYARIAH MANDIRI TBK. PERIODE 2011 - 2019
}

\author{
${ }^{1}$ Heri Tarmidi, ${ }^{2 *}$ Adji Widodo \\ Universitas Pamulang, Tangerang Selatan, Banten, Indonesia \\ *adjiwi8@gmail.com
}

\begin{abstract}
Abstrak
Penelitian ini bertujuan untuk mengetahui Pengaruh Capital Adequacy Ratio (CAR) dan Biaya Operasional Pendapatan Operasional (BOPO) Terhadap Profitabilitas Return On Asset (ROA) PT Bank Syariah Mandiri Tbk. data yang diperoleh bersumber dari laporan keuangan melalui Annual Report PT. Bank Syariah Mandiri (BSM) yang terdaftar pada Bursa Efek Indonesia periode tahun 2011-2019. Analisa data dilakukan dengan metode statistik deskriptif kuantitatif, Dari penelitian ini, dapat disimpulkan hasil Uji Simultan menunjukan bahwa secara simultan CAR dan BOPO secara bersamasama berpengaruh positif dan signifikan terhadap ROA PT Bank Syariah Mandiri Tbk. Hal ini dapat dibuktikaan dari hasil Fhitung lebih besar dari F tabel yaitu $(10,09>5,14)$. Dan Nilai signifikan lebih kecil dari 0,05 yaitu $(0012<0,05)$. Adapun Koefisien determinasi dengan hasil R2 = 0,771 atau 77,1\%.

Kata Kunci: Capital Adequacy Ratio (CAR), Biaya Operasional Pendapatan Operasional (BOPO) dan Return On Asset (ROA).
\end{abstract}

\section{Abstract}

This study aims to determine the effect of the Capital Adequacy Ratio (CAR) and Operating Costs Operating Income (BOPO) on the Profitability of Return on Assets (ROA) of PT Bank Syariah Mandiri Tbk. The data obtained are sourced from financial reports through the Annual Report of PT. Bank Syariah Mandiri (BSM), which is listed on the Indonesia Stock Exchange for the period 2011-2019. Data analysis was performed using quantitative descriptive statistical methods, From this study, it can be Simultaneous test results show that simultaneously CAR and BOPO together have a positive and significant effect on ROA of PT Bank Syariah Mandiri Tbk. This can be proven from the results of Fcount greater than Ftable, namely $(10.09>5.14)$. And the significant value is smaller than 0.05 , namely $(0012<0.05)$. The coefficient of determination with the results $R 2$ $=0.771$ or $77.1 \%$.

Keywords: Capital Adequacy Ratio (CAR), Operational Cost of Operating Income (BOPO) and Return On Assets (ROA).

\section{PENDAHULUAN}

Di era yang semakin maju ini, tentunya perkembangan di sektor ekonomi semakin pesat. Perkembangan tersebut disebabkan, salah satunya karena semakin mudahnya perusahaan dalam mencari dan mendapatkan dana. Karena itu, persaingan antar perusahan dalam meningkatkan citra perusahaannya semakin tinggi. Salah satu alternatif bagi perusahaan untuk mendapatkan dana atau penambahan modal adalah melalui investasi di pasar modal yaitu harga saham. Harga saham merupakan harga penutupan pasar saham selama periode pengamatan untuk tiap-tiap jenis saham yang dijadikan sampel dan pergerakannya senantiasa diamati oleh para investor. Harga saham mencerminkan juga nilai dari suatu perusahaan.

Manajemen keuangan salah satu aktivitas yang mencakup perusahaan yang berhubungan dengan memperoleh dana, menggunakan dana dan mengelola asset sesuai tujuan perusahaan secara menyeluruh.

Bank Syariah salah satu sistim bank 
yang kegiatan usahanya berdasarkan atas prinsip syariah yakni berdasarkan hukum Islam yang di atur oleh majelis ulama dalam sistim keadilan dan keseimbangan. Dilihat dari parameter rasio pembiayaan terhadap dana pihak ketiga dan ekuitas (FDR) financing to deposit ratio Bank Syariah di Indonesia telah memberikan konstribusinya secara positif bagi perekonomian nasional yang telah mencapai rata-rata $105 \%$. Dalam keuangan dikrnal dengan istilah ROA yaitu salah satu indikator yang mempunyai fungsi mengukur tingkat Profitabilitas,).

Jika modal mengalami peningkatan maka kesehatan bank yang terkait dengan rasio permodalan (CAR) semakin meningkat Barus (2011).

Menurut penelitian terdahulu dengan data Time Series periode 2008/1 - 2017/3 yang di analisis dengan regresi linier berganda didapatkan hasil bahwa FDR berpengaruh signifikan positif terhadap ROA, sedangkan CAR tidak berpengaruh signifikan terhadap ROA serta NPF dan BOPO berpengaruh signifikan negatif terhadap ROA. Oleh karena itu, untuk meningkatkan profit Bank Syariah mandiri perlu ditingkatkan pembiayaan (FDR dinaikan) dengan risiko rendah (NPF rendah) dan efisiensi bank ( BOPO diturunkan) Secara parsial Variabel Non Performing Financing (NPF) dan Financing to Deposit Ratio (FDR), tidak ada pengaruh terhadap Return On Asset (ROA). Sedangkan variabel Biaya Operasional Pendapatan Operasional (BOPO) berpengaruh negatif terhadap Return On Asset (ROA). Capital Adequacy Ratio (CAR) tidak terdapat pengaruh negatif signifikan antara CAR terhadap ROA. Variabel Inflasi dan Nilai tukar juga tidak mempunyai pengaruh terhadap Return On Asset (ROA), Sedangkan secara simultan variabel Non Performing Financing (NPF), Financing to Deposit Ratio (FDR), Biaya Operasional Pendapatan Operasional (BOPO), Capital Adequacy Ratio (CAR), Inflasi, dan Nilai Tukar tidak ada pengaruh signifikan terhadap Return On Asset (ROA). Konstribusi seluruh variabel bebas Non Performing Financing (NPF), Financing to
Deposit Ratio (FDR), Biaya Operasional terhadap Pendapatan Operasional (BOPO), Capital Adequacy Ratio (CAR), Inflasi, dan Nilai Tukar terhadap Return On Asset (ROA) sebesar $71,9 \%$ sisanya $28,1 \%$ dijelaskan oleh variabel lain diluar model penelitian ini Litriani (2016).

Nilai CAR dilihat dari data olahan BSM, BSM secara keseluruhan sudah memenuhi KPMM dan mendapatkan kategori sehat, melihat nilai CAR pada data olahan BSM menunjukan nilai CAR sebesar $16,26 \%$ dan mendapat kriteria "sangat sehat" berdasarkan surat edaran Bank Indonesia No. 6/23/DPNP Tahun 2004 dengan kriteria CAR $>=12 \%$ tetapi dengan tingginya nilai CAR menunjukan bahwa terdapat idle money. Hal ini menjadi fenomena yang menarik untuk diteliti dengan melihat rendahnya nilai ROA.

Berdasarkan data olahan BSM bahwa ROA pada tahun 2013 mengalami kenaikan perolehan laba perusahaan dibandingkan tahun 2013-2018, tetapi pada tahun 2019, laba BSM masih dibawah realisasi tahun 2012 yang mencapai 1,48\%. Hal ini menjadi fenomena yang menarik untuk diteliti karena mendapat faktor yang dapat mempengaruhi penurunan laba BSM tersebut. Salah satu faktor yang melatarbelakangi penurunan laba tersebut adalah biaya pencadangan yang naik dan pendapatan operasional yang tidak tumbuh signifikan.

Dalam hal ini penulis tertarik dan menelaah secara rinci untuk melakukan penelitian mengenai "Pengaruh Capital Adequacy Ratio (CAR), dan Biaya Operasional Pendapatan Operasional (BOPO) Terhadap Return On Asset (ROA) Pada Bank Syariah Mandiri Tbk Periode 2011-2019".

\section{TINJAUAN PUSTAKA}

Managemen keuangan merupakan suatu penggabungan antara ilmu dan seni yang mengkaji, membahas dan menganalisis cara managemen keuangan dengan menggunakan sumber daya perusahaan dengan tujuan mencari dana, mengelola dana dan membagi dana dengan 
tujuan memberikan profit bagi para pemegang saham dan keberlangsungan usaha Fahmi (2012).

Manajemen keuangan salah satu aktivitas yang mencakup perusahaan yang berhubungan dengan memperoleh dana, menggunakan dana dan mengelola asset sesuai tujuan perusahaan secara menyeluruh dengan kata lain berarti manajemen keuangan merupakan manajemen atau pengelolaan Andi, dkk (2018).

Dengan ini dapat dijelaskan bahwa manajemen keuangan bagaimana menggunakan sumber daya uang untuk mencapai sasaran yang telah diterapkan perusahaan dengan efektif yang menyangkut tentang penanaman modal, pembiayaan usaha serta membagi deviden. Sehingga keluar masuknya uang dapat dikontrol dengan baik Fitri (2019).

Laporan keuangan salah satu bagian dari proses pelaporan keuangan yang didalamnya terdapat seperti neraca, laporan laba rugi, laporan perubahan posisi keuangan serta sebagai catatan dari laporan lain seperti schedule dan informasi dan tambahan yang berkaitan dengan laporan tersebut seperti informasi keuangan Segmen industri dan geografis serta pengungkapan pengaruh perubahan harga Tumilar (2019). Laporan keuangan menyediakan berbagai informasi yang dibutuhkan oleh manajer keuangan seperti informasi mengenai laporan keuangan di dalam perusahaan.

\section{Capital Adequacy Ratio (CAR)}

CAR yang dimaksud adalah rasio yang memperlihatkan seberapa besar seluruh aktiva bank Syariah Mandiri Tbk yang mengandung faktor pendukung risiko (kredit, penyertaan tagihan pada bank lain). Seberapa besar jumlah aktiva pada bank yang mengandung risiko yang ikut dibiayai dari modal sendiri disamping memperoleh dana. Suhardjono (2018).

Berdasarkan Surat Edaran Bank Indonesia Nomor 13/30/DPNP Tanggal 16 Desember 2011, rasio CAR dapat dirumuskan sebagai berikut :

$$
\mathrm{CAR}=\frac{\text { Modal Bank }}{\text { ATMR }} \times 100 \%
$$

CAR merupakan indikator terhadap kemampuan bank untuk menutup Penurunan Aktivanya sebagai akibat dari kerugian-kerugian bank yang disebabkan oleh aktiva berisiko. CAR ini didasarkan prinsip bahwa setiap penanaman yang mengandung risiko harus disediakan jumlah modal sebesar presentase terhadap jumlah penanaman, semakin besar rasio tersebut akan semakin baik posisi modal. Sesuai dengan standar Bank of International Settlements (BIS) seluruh bank yang ada di Indonesia wajib untuk menyediakan modal minimum sebesar $8 \%$ dari Aktiva Tertimbang Menurut Risiko (ATMR).

\section{Biaya Operasional Pendapatan Operasional (BOPO)}

BOPO salah satu rasio yang menunjukan besar perbandingan antara beban atau biaya operasional terhadap pendapatan operasional suatu perusahaan pada periode tertentu.

Rasio perubahan $\mathrm{BOPO}$ nilainya sangat diperhatikan terhadap sektor perbankan karena kriteria penentuan tingkat kesehatan bank oleh Bank Indonesia adalah besaran rasio. Bank yang memiliki nilai rasio $\mathrm{BOPO}$ tinggi menunjukkan bahwa bank tersebut tidak beroperasi dengan efisien karena tingginya nilai rasio artinya menunjukan besarnya jumlah biaya operasional yang harus dikeluarkan oleh pihak bank untuk memperoleh pendapatan operasional. Selain itu, akan berhubungan dengan jumlah laba yang akan diperoleh karena semakin besarjumlah biaya operasional maka akan memperkecil jumlah laba yang akan diperoleh. Hal ini didasarkan pada biaya atau beban operasional bertindak sebagai faktor pengurang dalam laporan laba rugi.

Semakin kecil rasio maka semakin efisien biaya operasional yang dikeluarkan bank bersangkutan. Biaya Operasional Pendapatan Operasional (BOPO) sebagai upaya bank untuk meminimalkan risiko operasional, yang merupakan ketidakpastian mengenai kegiatan usaha 
bank. Risiko operasional tersebut berasal dari kerugian operasional, seperti penurunan keuntungan yang dipengaruhi oleh struktur biaya operasional bank, kemungkinan terjadinya kegagalan atas jasa-jasa dan penawaran produk-produk. Bank Indonesia menetapkan angka terbaik untuk rasio BOPO adalah dibawah $90 \%$, karena jika rasio BOPO melebihi 90\% hingga mendekati angka 100\% maka bank tersebut dapat dikategorikan tidak efisien dalam menjalankan operasionalnya.

Efisiensi operasional diukur dengan membandingkan besarnya biaya operasional dengan pendapatan operasional (BOPO) Danupranata (2015). Rasio BOPO dihitung menggunakan rumus:

$$
\text { BOPO }=\frac{\text { Beban operasioanal }}{\text { Pendapatan Operasional }} \times 100 \%
$$

\section{Return On Asset (ROA)}

ROA mengukur kemampuan manajemen dan efisiensi dalam menggunakan aset perusahaan untuk menghasilkan keuntungan serta melaporkan total pengembalian yang diperoleh untuk semua penyedia modal.

Semakin besar ROA suatu perusahaan, semakin besar pula tingkat keuntungan yang dicapai perusahaan serta semakin baik pula posisi perusahaan tersebut dari segi penggunaan aset. ROA yang positif menunjukan bahwa dari total aktiva yang digunakan untuk beroperasi mampu memberikan laba kepada perusahaan. Suatu perusahaan yang memiliki nilai ROA yang tinggi positif maka perusahaan tersebut berpeluang besar dalam meningkatkan pertumbuhan modal sendiri.

ROA dapat dihitung dengan menggunakan rumus:

$$
\mathrm{ROA}=\frac{\text { Laba Bersih }}{\text { Total asset }} \times 100 \%
$$

\section{METODE PENELITIAN}

Penelitian ini merupakan penelitian kuantitatif yang menggunakan data sekunder yang diperoleh dari laporan keuangan yang telah dipublikasikan PT.
Bank syariah Mandiri periode 2011-2019 di website.

Tempat penelitian yang dipilih penulis adalah PT Bank Syariah Mandiri. Waktu penelitian dilakukan terhitung mulai dari bulan Oktober 2020 sampai dengan bulan Januari 2021, waktu ini digunakan untuk Pengajuan Proposal, pengambilan data dan penyusunan laporan hasil.

\section{PEMBAHASAN DAN HASIL PENELITIAN \\ Uji Asumsi Klasik}

1. Uji Normalitas

Dari hasil uji normalitas dapat disimpulkan bahwa nilai residual terdistribusi normal. Untuk mendapatkan tingkat uji normalitas yang signifikan maka penelitian ini juga menggunakan uji statistic non Parametic Kolmogorov Smirnov. Dari hasil output diketahui bahwa nilai signifikansi (Asymp. Sig 2-tailed) sebesar 0,103 karena nilai signifikansi lebih dari 0,05 dapat disimpulkan bahwa nilai residual terdistribusi dengan normal.

Tabel 1. Kolmogorow-Smirnov Test

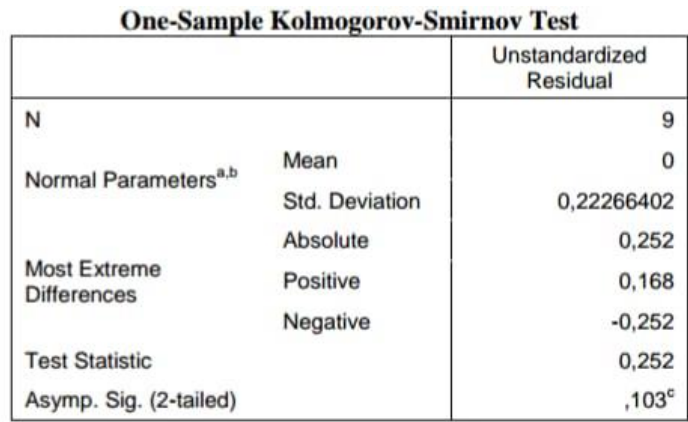

Sumber : Hasil olah data SPSS

2. Uji Heteroskedastisitas

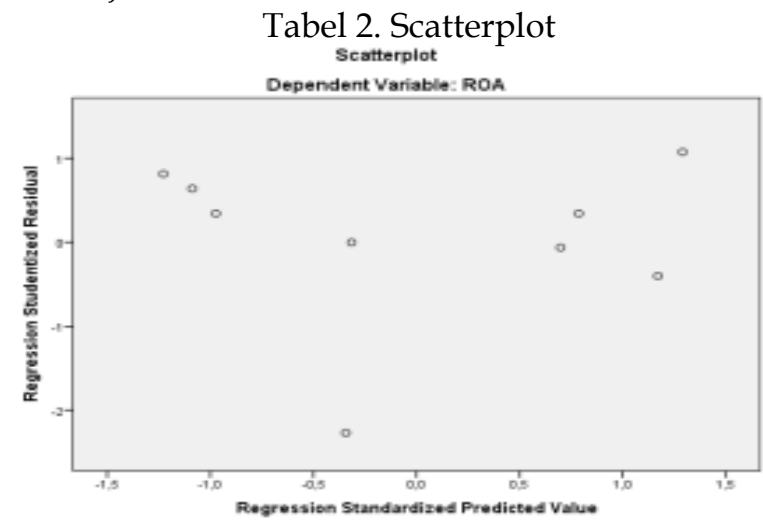


3. Uji Multikolinearitas

Tabel 3. Hasil Uji Multikoliniearitas

\begin{tabular}{|l|r|r|}
\multicolumn{2}{c|}{ Coefficients $^{\mathrm{a}}$} \\
\hline \multirow{2}{*}{\multicolumn{1}{|c|}{ Model }} & \multicolumn{2}{|c|}{ Collinearity Statistics } \\
\cline { 2 - 3 } \multicolumn{1}{|c|}{} & Tolerance & \multicolumn{2}{c|}{ VIF } \\
\hline (Constant) & & \\
CAR & 0,823 & 1,214 \\
BOPO & 0,823 & 1,214 \\
\hline
\end{tabular}

Berdasarkan tabel diatas maka dapat diketahui nilai VIF untuk masingmasing variabel penelitian sebagai berikut:

a. Nilai Tolerance variabel CAR sebesar $0,823>0,1$ dan nilai VIF CAR 1,214 < 10 maka dapat disimpulkan variable CAR tidak terjadi multikolinearitas.

b. Nilai Tolerance variable BOPO sebesar $0,823>0,1$ dan nilai BOPO VIF 1,214 $<10$ maka dapat disimpulkan variable BOPO tidak terjadi multikolinearitas.

4. Uji Autokorelasi

Tabel 4. Uji Autokorelasi dengan Durbin Watson

Koefisien Determinasi $\left(\mathrm{R}^{2}\right)$ Model Summary

\begin{tabular}{|l|c|c|c|c|c|}
\hline Model & $R$ & $\begin{array}{c}R \\
\text { Square }\end{array}$ & $\begin{array}{c}\text { Adjusted } R \\
\text { Square }\end{array}$ & $\begin{array}{c}\text { Sid. Error of the } \\
\text { Estimate }\end{array}$ & Durbin-Watson \\
\hline 1 &, $878^{8}$ & 0,771 & 0,694 & 0,25711 & 2,193 \\
\hline
\end{tabular}

Sumber: Hasil Olah Data SPSS

Adapun nilai dL sebesar 0,6291, dU sebesar 1,6993, 4-dl sebesar 3,3709 dan 4dU sebesar 2.3007 pada tabel Durbin Watson pada taraf untuk variabel independen $(\mathrm{k})=2$ dan $(\mathrm{n})=9$ data dengan nilai signifikansi 0.05 dan nilai Durbin Watson sebesar 2,193. Tampak bahwa yang masuk dalam kategori terletak diantara dU $<\mathrm{d}<4-\mathrm{dU}(1,6993$ $\leq 2,193 \leq 2,3007)$ berarti tidak bisa mengambil keputusan apapun (non decision).

Untuk memperkuat hasil ini diperlukan uji run-test dimana uji ini penggunaan autokorelasi terjadi jika signifikannya dibawah 0,05 berikut adalah uji autokorelasi dengan run-test yaitu:
Tabel 5. Run Test

\begin{tabular}{|c|c|}
\hline \multicolumn{2}{|c|}{ Runs Test } \\
\hline & $\begin{array}{c}\text { Unstandardized } \\
\text { Residual }\end{array}$ \\
\hline Test Value" & 0,06867 \\
\hline Cases < Test Value & 4 \\
\hline Cases $>=$ Test Value & 5 \\
\hline Total Cases & 9 \\
\hline Number of Runs & 6 \\
\hline$z$ & 0,04 \\
\hline Asymp. Sig. (2-tailed) & 0,968 \\
\hline
\end{tabular}

Sumber : Hasil Olah Data SPSS

Dari hasil uji statistik run-test pada tabel di atas diperoleh dengan nilai 0,968 lebih besar dari taraf signifikan 0,05 $(0,968>0,05)$ maka dapat ditarik kesimpulan bahwa data tidak terjadi problem atau gangguan autokorelasi pada model penelitian atau memenuhi asumsi klasik autokorelasi.

\section{Analisis Regresi Linier}

1.Regresi Linier Sederhana

Tabel 6. Pengaruh CAR terhadap ROA

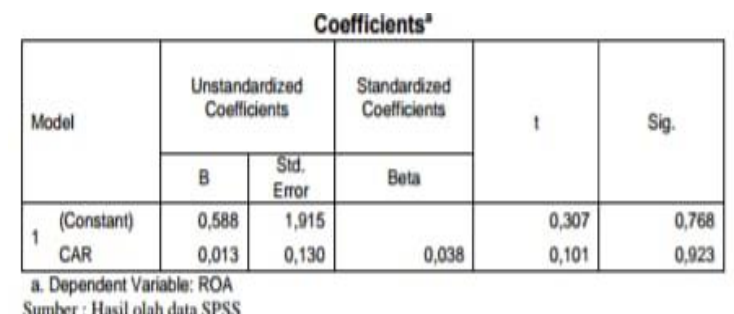

Sumber: Hasil olah data SPSS

Dari persamaan diatas dapat

diartikan :

a. Angka Constant dari Unstandardized Coefficients, dalam kasus ini bernilai sebesar 0,588 yang memiliki arti bahwa jika tidak ada CAR (X1) maka nilai ROA (Y) sebesar 0,588\%.

b. Angka Koefisien regresi bernilai 0,013 artinya bahwa setiap CAR (X1) naik sebesar 1\% maka ROA meningkat sebesar $0,013 \%$.

c. Berdasarkan Output diatas diketahui nilai signifikansi (Sig) sebesar 0,923 lebih besar dari $>0,05$, sehingga dapat disimpulkan bahwa Ho diterima dan Ha ditolak, yang berarti “ tidak ada pengaruh CAR terhadap ROA". 
Tabel 7. Pengaruh BOPO terhadap ROA

\begin{tabular}{|c|c|c|c|c|c|}
\hline \multirow{2}{*}{ Model } & \multicolumn{2}{|c|}{$\begin{array}{l}\text { Unstandardized } \\
\text { Coefficients }\end{array}$} & \multirow{2}{*}{$\begin{array}{c}\begin{array}{c}\text { Standardized } \\
\text { Coefficients }\end{array} \\
\text { Beta } \\
\end{array}$} & \multirow{2}{*}{$t$} & \multirow{2}{*}{ Sig. } \\
\hline & B & $\begin{array}{l}\text { Sid. } \\
\text { Error }\end{array}$ & & & \\
\hline (Constant) & 3,386 & 0.612 & & 5,536 & 0,001 \\
\hline BOPO & $-0,031$ & 0,007 & $-0,851$ & $-4,294$ & 0,004 \\
\hline
\end{tabular}

Dari persamaan diatas dapat diartikan :

a. Angka Constant dari Unstandardized Coefficients, dalam kasus ini bernilai sebesar 3,386 artinya jika tidak ada BOPO (X2) maka nilai ROA (Y) sebesar 3,386\%.

b. . Angka Koefisien regresi bernilai 0,013 artinya setiap BOPO $(X 2)$ naik

c. sebesar $1 \%$ maka ROA (Y) meningkat sebesar $-0,031 \%$.

d. Berdasarkan Output diatas diketahui nilai signifikansi (Sig) sebesar 0,004 lebih kecil dari $<0,05$, sehingga dapat disimpulkan bahwa Ho ditolak dan Ha diterima, yang berarti " ada pengaruh CAR terhadap ROA".

2. Regresi Linier Berganda

Tabel 8.Hasil Regresi Linier Berganda

\begin{tabular}{|c|c|c|c|c|c|}
\hline \multicolumn{6}{|c|}{ Coefficients } \\
\hline \multirow{2}{*}{ Model } & \multicolumn{2}{|c|}{$\begin{array}{l}\text { Unstandardized } \\
\text { Coefficients }\end{array}$} & \multirow{2}{*}{$\begin{array}{c}\begin{array}{c}\text { Standardized } \\
\text { Coefficients }\end{array} \\
\text { Beta }\end{array}$} & \multirow[t]{2}{*}{1} & \multirow{2}{*}{ Sig. } \\
\hline & $B$ & Sid. Error & & & \\
\hline (Constant) & 1,314 & 1,145 & & 1,148 & 0,295 \\
\hline CAR & 0,189 & 0,084 & 0,483 & 2,242 & 0,066 \\
\hline BOPO & $.0,04$ & 0,009 & $\cdot 0,964$ & $-4,475$ & 0,004 \\
\hline
\end{tabular}

Sumber: Hasil olah Data SPSS

Rumus $=\mathrm{Y}=\mathrm{a}+\mathrm{B} 1 \mathrm{X} 1+\mathrm{B} 2 \mathrm{X} 2+\mathrm{e}$ $\mathrm{Y}=1,314+0,189 \mathrm{X} 1+(-0,04) \mathrm{X} 2+\mathrm{e}$

Interprestasi dari persamaan regresi linier berganda diatas memiliki asumsi sebagai berikut:

1. Nilai konstanta sebesar 1,314 menyatakan apabila variabel CAR (X1) dan BOPO (X2) memiliki nilai sama dengan (0), maka akan meningkatkan ROA (Y) Sebesar 1,314.

2. Nilai koefisien regresi variabel CAR (X1) sebesar 0,189 artinya, jika CAR (X1) mengalami kenaikan maka ROA (Y) akan meningkat sebesar 0,189.

3. Nilai koefisien regresi variabel BOPO (X2) sebesar $-0,04$ artinya, jika BOPO
(X2) mengalami kenaikan maka ROA

(Y) akan meningkat sebesar 0,04.z

\section{UJI HIPOTESIS}

1. Uji Signifikansi Parameter Individual (T-test)

Berdasarkan hasil Coefficients model 1, maka diperoleh hasil sebagai berikut :

a. Pengujian Hipotesis pertama $\left(\mathrm{H}_{1}\right)$

Nilai $t_{\text {hitung }}$ sebesar 2,242 sedangkan $t_{\text {tabel }}$ dengan tingkat signifikansi 0,05 adalah $(\mathrm{dk})=\mathrm{n}-\mathrm{k}$ adalah $9-3=6$ diperoleh $t_{\text {tabel }}$ sebesar 2,447, dari hasil tersebut dengan melakukan perbandingan yaitu, $t_{\text {hitung }}(2,242)<t_{\text {tabel }}(2,447)$ sehingga ( $\mathrm{H}_{\mathrm{o}}$ diterima, $\mathrm{H}_{1}$ ditolak). Sedangkan nilai sig untuk CAR sebesar 0,066>0,05, maka secara parsial CAR tidak berpengaruh terhadap ROA.

b. Pengujian Hipotesis kedua $\left(\mathrm{H}_{2}\right)$

Nilai $t_{\text {hitung }}$ sebesar $-4,475$ sedangkan dengan tingkat signifikan $0,05(\mathrm{dk})=\mathrm{n}-\mathrm{k}$ adalah $9-2=7$ diperoleh $t_{\text {tabel }}$ sebesar 2,447, dari hasil tersebut dengan melakukan perbandingan yaitu, $t_{\text {hitung }}(-4,475)<$ $t_{\text {tabel }}(2,447)$ sehingga $\left(H_{o}\right.$ diterima, $H_{2}$ ditolak). Sedangkan nilai sig untuk BOPO sebesar 0,004 < 0,05, maka secara parsial $\mathrm{BOPO}$ berpengaruh negatif terhadap ROA.

2. Uji Signifikansi Simultant (Uji-F) Tabel 9. Hasil Pengujian Uji - F

\begin{tabular}{|c|c|c|c|c|c|}
\hline \multicolumn{6}{|c|}{ ANOVA $^{a}$} \\
\hline Model & $\begin{array}{l}\text { Sum of } \\
\text { Squares }\end{array}$ & df & $\begin{array}{l}\text { Mean } \\
\text { Square }\end{array}$ & $F$ & Sig. \\
\hline Regression & 1,334 & 2 & 0,667 & 10,09 &, $012^{b}$ \\
\hline Residual & 0,397 & 6 & 0,066 & & \\
\hline Total & 1,731 & 8 & & & \\
\hline
\end{tabular}

Berdasarkan Uji-F diatas dapat dilihat nilai $F_{\text {hitung }} 10,09>F_{\text {tabel }}$ 5,14 dan nilai sig 0,012<0,05 sehingga dapat disimpulkan bahwa CAR dan BOPO secara simultan berpengaruh positif signifikan terhadap ROA. 
3. Uji Koefisien determinasi $\left(\mathrm{R}^{2}\right)$

Dari hasil olah data diperoleh nilai koefisien determinasi sebesar 0,771 atau sama dengan $77,1 \%$ artinya bahwa rasio CAR dan BOPO berpengaruh 77,1\% terhadap ROA. Sedangkan sisanya sebesar 22,9\% dipengaruhi variabel lain yang tidak diteliti dalam penelitian.

$R$-square menjelaskan seberapa besar variasi yang dibebaskan oleh $\mathrm{X}$ dari hasil perhitungan diperoleh nilai Adjusted R-square koefisien determinasi sebesar 0,694 atau sama dengan dengan $69,4 \%$. Artinya 69,4\% ROA dipengaruhi oleh kedua variabel CAR dan BOPO. Dan sisanya sebesar 30,6\% dipengaruhi oleh variabel yang tidak diteliti dalam penelitian lain.

\section{PENUTUP}

\section{Kesimpulan}

Berdasarkan hasil analisis diatas maka dapat diambil kesimpulan sebagai berikut :

1. CAR Secara parsial tidak berpengaruh terhadap ROA, Artinya jika nilai CAR tinggi maka ROA belum tentu menunjukan kenaikan, seharusnya jika nilai CAR naik mempengaruhi laba perusahaan juga akan meningkat.

2. BOPO Secara parsial berpengaruh negatif terhadap ROA Artinya jika terjadi beban operasional meningkat akan menurunkan tingkat laba perusahaan.

3. CAR dan BOPO Secara simultan (bersama-sama) berpengaruh positif dan signifikan terhadap ROA.

\section{Saran}

1. Untuk manajemen PT. Bank Syariah Mandiri Tbk diharapkan mampu untuk meningkatkan CAR dan BOPO agar diperiode kedepan dapat meningkatkan ROA.

2. Untuk penelitian selanjutnya, diharapkan lebih mengembangkan penelitian dengan menambahkan variabel-variabel lainnya agar penelitian menjadi lebih baik..
3. Penelitian selanjutnya mampu memperbaiki kekurangan yang ada dalam penelitian ini.

\section{DAFTAR PUSTAKA}

Adrianto dan Firmansyah, A. (2019). Managemen Bank Syariah. Qiara Media.

Amwaluna. (2018). Pengaruh CAR, NPL, dan FDR terhadap Profitabilitas bank syariah di indonesia . Jurnal Ekonomi dan Keuangan Syariah VOL 2 , 1-18.

Andi, dkk. (2018). Pengaruh Kinerja Keuangan terhadap Harga Saham. Jurnal Organisasi dan Manajemen, 4765.

Barus. (2011). Analisis Profitabilitas dan Likuiditas terhadap CAR pada Institusi

Budisantoso. (2011). bank dan Lembaga Keuangan Lainnya Edisi Dua. Jakarta: Salemba Empat.

Danupranata, G. (2015). Buku Ajar Manajemen Perbankan Syariah. Jakarta: Salemba Empat.

David Wijaya, (2017). “Manajemen Keuangan Konsep dan Penerapannya". Jakarta: PT. Gasindo.

Dewi, Aminar Sutra, (2017). Pengaruh CAR, BOPO, NPL, NIM dan LDR Terhadap ROA pada Perusahaan disektor Perbankan yang terdaftar di BEI Periode 2012-2016. Jurnal pundi Research Of Managemen Accounting, and Economics Vol 1 No 3.

Fahmi. (2012). Pengantar managemen keuangan. Bandung: Penerbit Alfabeta.

Fitri, D. d. (2015). Analisis Pengaruh Kinerja Keuangan, Manajemen Resiko dan Manajemen Modal Kerja terhadap Return Saham. Jurnal Manajemen Indonesia , 1-16.

Frianto. (2017). Managemen Dana dan Kesehatan Bank. Jakarta: PT Rineka Cipta.

Ghozali, I. (2011). Aplikasi Analisis Multivariate dengan Program SPSS. Semarang: Universitas Diponegoro.

Gitman, L, j, (2015). Principles Of Manajerial Finance. Baston: Pearson Education. 
Hasibuan, m. S. (2011). Dasar-dasar Perbankan . Jakarta: PT.Bumi Aksara.

Huda, K. (2017). manajemen Keuangan Pribadi Mahasiswa Ekonomi Syari'ah Perspektif Managemen keuangan Syari'ah. Mataram: Uin Mataram.

Kasmir. (2010). Pengantar Managemen Keuangan. Edisi Kedua. Jakarta: Kencana Prenada Media Group.

Lili, Y. d. (t.thn.). Pengaruh CAPITAL Ne DUCATION.

Lutfi, A. M., Erlangga, H., Nurjaya, N., Priadana, S., \& Dwiwarman, D. A. (2021). Pengaruh Capital Adequacy Ratio Dan Bopo Ratio Terhadap Return On Asset Pada Pt. Bank Muamalat Indonesia, Tbk Periode 2010-2019. Jurnal Ekonomi Efektif, 3(3).

Mandiri, P. B. (2013 ). Laporan Tahunan Bank Syariah Mandiri 2013. Jakarta: PT Bank Syariah Mandiri.

N. Rusnaeni, Sefti R (2019). Pengaruh CAR dan NPL Terhadap ROA pada PT. Bank Sinarmas Tbk Periode Tahun 2011-2017. E-Jurnal Ekonomi Efektif Vol 2(1).

Nadi Hernadi, S. j. (2020). Pengaruh FDR, BOPO, NPL dan CAR Terhadap ROA pada PT Bank Syariah Mandiri Periode 2012-2019. Geo Ekonomi Vol 11 , 74-89.

Najibullah, et al. (2021). Pengaruh non Performing Financing dan Financing to Deposit Ratio terhadap Pembiayaan pada Bank DKI Syariah. Jurnal Neraca Peradaban. Volume 1. Issue1. Pages 48-5

Nugroho, dkk. (2019). Analisa Pengaruh Perputaran Khas dan Perputaran Piutang Terhadap ROA pada Perusahaan LQ45 yang Terdaftar di BEI Tahun 2012-2017. Jurnal Inovasi Bisnis , 20-25.

Nurjaya, et al (2021). Pengaruh Liquiditas dan Profitabilitas terhadap Return Saham: Studi Empiris Pada Perusahaan Real Estate Dan Property Yang Terdaftar Di Bursa Efek Indonesia Tahun 2017-2019. Jurnal
Tadbir Peradaban Volume 1. Issue.1. Pages 60-68.

Pratiwi, Wiagustini, (2016). Pengaruh CAR, BOPO, NPL dan LDR Terhadap Profitabilitas. Jurnal manajemen Vol 5 No 4.

Pujiati, H., Sunarsi, D., Affandi, A., \& Anggraeni, N. (2021). Effect of ISO 9001: 2015 Quality Management Implementation in Education on School Performance. Journal of Contemporary Issues in Business and Government, 27(1), 1848-1855.

Rahmah. (2018). Analisis Pengaruh CAR, FDR, NPF, BOPO Terhadap Profitabilitas (Return On Asset) Pada Bank Syariah Mandiri Periode Tahun 2013-2017. 1-112.

Ramadhani, I. (2018). Analisis Pengaruh FDR, CAR, NPL dan BOPO Terhadap Profitabilitas Bank Syariah di Indonesia.

Salam, A., Hikmat, I., Haquei, F., \& Badariah, E. (2021). The Influence of Share Ownership, Funding Decisions, Csr and Financial Performance of Food Industry. Annals of the Romanian Society for Cell Biology, 12698-12710.

Sentosa, S. (2012). Hukum Perbankan bandung. Bandung: mandar Maju.

Siswati. (2013). Analisis Penyaluran Dana Bank Syariah. Jurnal Dinamika Manajemen , 82-92.

Sudarmawanti, E. (2011). Pengaruh CAR, NPL, BOPO, NIM dan LDR terhadap ROA. Salatiga: Otoritas Jasa Keuangan .

Sugiyono.s (2016). Metode Penelitian Kuantitatif, Kualitatif, RED. Bandung: Alfabeta. CV.

Suhardjono, K. d. (2011). Manajemen Perbankan. Yogyakarta: BPFE. 